\title{
Analisis Rasio Keuangan Untuk Mengukur Kinerja Keuangan Pada PT.Pelabuhan Indonesia I (Persero) Periode 2013-2017
}

(Berdasarkan Keputusan Menteri BUMN Nomor: KEP-100/MBU/2002)

\author{
Rosanna Purba ${ }^{1}$, Renika Hasibuan ${ }^{2 *}$, Prananda Akbar Syam ${ }^{3}$ \\ ${ }^{1,2,3)}$ Universitas Sari Mutiara Indonesia

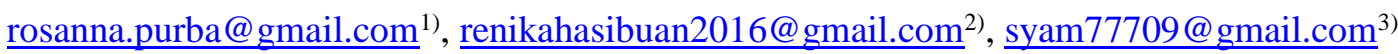

*Penulis Korepondensi

Submitted: 4 Juni 2021

Accepted: 1 Agustus 2021

Published: 4 Agustus 2021

\section{ABSTRACT}

This study aims to determine and analyze the level of financial performance at PT. Pelabuhan Indonesia I (Persero) for the period 2013-2017 in terms of financial ratio analysis based on the Decree of the Minister of BUMN No: KEP-100/ MBU/2002. Information on the condition of the company's financial performance is necessary to maintain the company's existence from competition. The analytical method used is descriptive method with a quantitative approach, with data collection techniques in the form of documentation studies. The data analyzed were the financial statements of PT. Pelabuhan Indonesia I (Persero), which is the income statement and statement of financial position (balance sheet) for the period 2013-2017. Assessment of the performance level from the financial aspect based on the Decree of the Minister of BUMN No: KEP-100/MBU/2002 uses 8 (eight) financial ratio indicators, which is Return On Equity, Return On Investment, Cash Ratio, Current Ratio, Collection Periods, Inventory Turnover, Total Asset Turn Over, and the Ratio of Equity Capital to Total Assets. The results of the assessment of financial performance PT. Pelabuhan Indonesia I (Persero) received a healthy predicate with the AA category in a row during the period 2013 to 2017. The results of this research can be used to evaluate the financial performance assessment indicators of PT. Pelabuhan Indonesia I (Persero) based on the Decree of the Minister of BUMN No: KEP-100/ MBU/2002.

Keywords: Cash Ratio, Current Ratio, Decree of the Minister of BUMN No: KEP-100/MBU/2002, Financial Performance, Financial Ratios

\section{PENDAHULUAN}

Perkembangan dunia usaha dalam situasi perekonomian yang semakin terbuka perlu dilandasi dengan sarana dan sistem penilaian kinerja yang dapat mendorong perusahaan ke arah peningkatan efisiensi dan daya saing. Kemajuan suatu perusahaan dapat dilihat dan dinilai dari aspek kinerja keuangannya. Bentuk paling umum informasi suatu perusahaan adalah seperangkat laporan keuangan yang dibuat berdasarkan pedoman dan standar yang berlaku. Laporan keuangan yang telah dibuat, mencerminkan keputusan yang dibuat manajemen pada masa lalu maupun sekarang. Menurut (Fahmi, 2017), kinerja keuangan perusahaan adalah suatu analisis yang dilakukan untuk melihat sejauh mana suatu perusahaan telah melaksanakan dengan menggunakan aturan-aturan secara baik dan benar. Kinerja keuangan perusahaan merupakan gambaran posisi keuangan perusahaan dan menunjukkan hasil usaha selama periode tertentu, yang diperoleh dengan menganalisa laporan keuangan.

Menurut (Rudianto, 2013), kinerja keuangan perusahaan adalah hasil atau prestasi yang telah dicapai oleh manajemen perusahaan dalam mengelola aset perusahaan secara efektif selama periode tertentu. Kinerja keuangan sangat dibutuhkan oleh perusahaan untuk mengetahui dan mengevaluasi tingkat keberhasilan perusahaan berdasarkan aktivitas keuangan yang telah dilaksanakan. Kinerja keuangan perusahaan merupakan gambaran posisi keuangan perusahaan dan 
menunjukkan hasil usaha selama periode tertentu, yang diperoleh dengan menganalisa laporan keuangan.Salah satu alat yang digunakan untuk menilai kinerja keuangan perusahaan yaitu dengan menggunakan laporan-laporan keuangan perusahaan. Laporan keuangan perusahaan tersebut dapat di analisis dengan menggunakan rasio keuangan yang akan diketahui secara jelas tentang hasil usaha yang dicapai oleh perusahaan. Data keuangan tersebut kemudian di analisis lebih lanjut sehingga akan diperoleh informasi yang dapat mendukung keputusan yang dibuat, dengan menganalisis data keuangan tahun-tahun sebelumnya maka dapat diketahui tingkat profitabilitas, tingkat solvabilitas, tingkat likuiditas dan stabilitas usaha, dan juga tingkat risiko atau tingkat kinerja suatu perusahaan.

Hasil penilaian tersebut untuk melihat kondisi kinerja perusahaan selama satu periode. Apabila kinerja keuangan perusahaan dinyatakan sehat maka akan dipercaya eksistensinnya, sehingga mampu meningkatkan daya saing perusahaan. Dan jika perusahaan yang memiliki kinerja keuangan yang tidak sehat bukan hanya membahayakan perusahaan itu sendiri akan tetapi dapat merugikan pihak lain seperti investor. Selain itu, sebuah perusahaan bisa dikatakan sukses apabila ditunjang dengan kinerja keuangan yang baik pula, dengan kinerja yang baik akan menunjukkan keberhasilan perusahaan dalam mengelola sumber daya keuangannya.

Dalam hal ini, pemerintah melalui Menteri BUMN mengeluarkan sebuah keputusan yang dapat digunakan sebagai indikator dalam menentukan kinerja aspek keuangan sebuah perusahaan BUMN infrastruktur maupun non infrastruktur. Keputusan Menteri BUMN tersebut berisi tentang tata cara menganalisa hingga indikator-indikator apa saja yang di teliti dalam menentukan suatu kinerja keuangan perusahaan BUMN. Penilaian atas kinerja keuangan perusahaan BUMN dilakukan berdasarkan atas Keputusan Menteri BUMN Nomor: KEP-100/MBU/2002, tentang Penilaian Tingkat Kinerja Badan Usaha Milik Negara (BUMN). Mengacu pada keputusan tersebut, ada 3 (tiga) aspek yang menjadi penilaian yaitu aspek keuangan, aspek operasional, dan aspek administrasi. Berhubung penelitian ini dilakukan untuk mengetahui kinerja perusahaan dari aspek keuangan PT. Pelabuhan Indonesia I (Persero), maka aspek operasional dan aspek administrasi tidak dibahas dalam penelitian ini.

Dalam aspek keuangan pada keputusan Menteri BUMN tersebut, terdapat 8 (delapan) rasio keuangan yang digunakan sebagai indikator tingkat kinerja keuangan BUMN. Rasio-rasio tersebut adalah Return On Equity (ROE), Return On Investment (ROI),Cash Ratio, Current Ratio, Collection Periods (CP), Perputaran Persediaan (PP), Total Asset Turn Over (TATO), Rasio Total Modal Sendiri Terhadap Total Aset (TMS Terhadap TA).

Sebagai salah satu perusahaan BUMN non keuangan infrastruktur sektor perhubungan, PT. Pelabuhan Indonesia I (Persero) memiliki peran yang signifikan dalam industri kepelabuhanan di Indonesia. Pelabuhan sebagai infrastruktur transportasi laut mempunyai posisi yang sangat penting dan strategis untuk pertumbuhan industri dan perdagangan serta memberikan kontribusi bagi perekonomian dan pembangunan nasional karena merupakan bagian dari mata rantai dari sistem transportasi maupun logistik. Menilai baik atau tidaknya kinerja keuangan dalam perusahaan, maka dalam pelaksanaannya harus menggunakan pengukuran yang dapat dijadikan perbandingan. Ukuran perbandingan yang bisa dipakai adalah kinerja keuangan sebelumnya. Data yang digunakan sebagai input dalam analisis ini adalah laporan laba rugi dan laporan posisi keuangan serta dapat menilai seberapa jauh efektifitas dan efisiensi yang telah dilakukan perusahaan untuk tujuan tertentu. Adapun data aktiva lancar, aktiva tidak lancar, kewajiban lancar dan kewajiban jangka panjang akan ditampilkan pada tabel 1 dibawah ini.

Tabel 1. Data Aset \& Kewajiban PT. Pelindo I (Persero) 2013-2017 (dalam Ribuan)

\begin{tabular}{|c|c|c|r|r|}
\hline Tahun & $\begin{array}{c}\text { Aktiva } \\
\text { Lancar }\end{array}$ & $\begin{array}{c}\text { Aktiva Tidak } \\
\text { Lancar }\end{array}$ & $\begin{array}{c}\text { Kewajiban Jangka } \\
\text { Pendek }\end{array}$ & $\begin{array}{c}\text { Kewajiban Jangka } \\
\text { Panjang }\end{array}$ \\
\hline 2013 & 1.274 .053 .560 & 3.305 .243 .518 & 611.997 .155 & 1.176 .939 .048 \\
2014 & 1.478 .307 .670 & 3.364 .746 .420 & 727.173 .225 & 1.092 .746 .749 \\
2015 & 1.766 .673 .446 & 3.725 .242 .136 & 1.114 .460 .838 & 737.229 .655 \\
2016 & 2.481 .343 .189 & 4.820 .008 .121 & 1.511 .586 .760 & 1.488 .588 .639 \\
2017 & 2.209 .548 .447 & 6.297 .594 .869 & 1.823 .137 .754 & 1.779 .781 .801 \\
\hline
\end{tabular}

Sumber : Laporan Keuangan Tahunan PT. Pelabuhan Indonesia I (Persero) 
Dari tabel 1 diatas dapat diketahui bahwa terdapat kenaikan pada aktiva tidak lancar dan kewajiban jangka pendek setiap tahunnya, sedangkan pada aktiva lancar perusahaan mengalami fluktuasi penurunan pada tahun 2017 yaitu senilai Rp.2.209.548.446.582, yang jika dibandingkan dengan tahun sebelumnya yaitu senilai Rp.2.481.343.189.025. Begitu juga pada kewajiban jangka panjang yang mengalami fluktuasi penurunan pada tahun 2014 yaitu senilai Rp.1.092.746.748.507 dan tahun 2015 yaitu senilai Rp.737.229.655.250, yang jika dibandingkan dengan tahun 2013 yaitu senilai Rp.1.176.939.047.516.

Dari data diatas yang diperoleh perusahaan menunjukan bahwa terjadi ketidakstabilan pada data keuangan tersebut. Adanya fenomena tersebut, peneliti tertarik untuk mengetahui kondisi kinerja keuangan pada perusahaan BUMN PT. Pelabuhan Indonesia I (Persero). Metode penilaian kinerja keuangannya berdasarkan Keputusan Menteri BUMN Nomor: KEP-100/MBU/2002, yang digunakan untuk mengetahui kinerja keuangan perusahaan sesuai dengan peraturan yang ada pada perusahaan BUMN. Berdasarkan uraian diatas, maka pentingnya mengetahui kinerja keuangan tersebut sebagai sebuah alat tolak ukur kinerja suatu perusahaan. Atas dasar inilah maka peneliti tertarik mengambil judul penelitian, "Analisis Rasio Keuangan Untuk Mengukur Kinerja Keuangan Pada PT. Pelabuhan Indonesia I (Persero) Periode 2013-2017 (Berdasarkan Keputusan Menteri BUMN Nomor: KEP-100/MBU/2002)".

\section{Uraian Teori}

\section{STUDI LITERATUR}

Kinerja keuangan merupakan suatu usaha yang telah dilakukan oleh perusahaan yang dapat mengukur kemampuan perusahaan dalam memenuhi kewajiban dan menghasilkan laba, sehingga dapat melihat potensi dan pertumbuhan perusahaan dengan mengandalkan sumber daya yang ada. Suatu perusahaan dapat dikatakan berhasil apabila telah mencapai standar dan tujuan yang telah ditetapkan. Menurut (Hery, 2015), analisis laporan keuangan merupakan suatu proses untuk membedah laporan keuangan ke dalam unsur-unsurnya dan menelaah masing-masing dari unsur tersebut dengan tujuan untuk memperoleh pengertian dan pemahaman yang baik dan tepat atas laporan keuangan itu sendiri. Sedangkan menurut (Kasmir, 2015), analisis laporan keuangan merupakan penyusunan laporan keuangan berdasarkan data yang relevan, serta dilakukan dengan prosedur akuntansi dan penilaian yang benar, dan akan terlihat kondisi keuangan perusahaan yang sesungguhnya.

Perlunya menganalisis laporan keuangan untuk memahami gambaran aktivitas dalam perusahaan yang tercermin dalam laporan tersebut agar hasil analisisnya dapat memuaskan. Laporan keuangan menjadi lebih bermanfaat untuk pengambilan keputusan, apabila dengan informasi keuangan tersebut dapat di prediksi apa yang akan terjadi di masa yang akan datang. Menurut (Munawir, 2016), tujuan analisis laporan keuangan adalah untuk memperoleh informasi yang berhubungan dengan posisi keuangan perusahaan dan hasil-hasil yang telah dicapai oleh perusahaan.

Menurut (Indonesia, 2019), laporan keuangan merupakan bagian dari proses pelaporan keuangan. Laporan keuangan yang lengkap biasanya meliputi, laporan laba rugi, laporan perubahan ekuitas, laporan posisi keuangan, laporan arus kas atau laporan arus dana, catatan dan laporan lain serta materi penjelasan yang merupakan bagian integral dari laporan keuangan. Analisis laporan keuangan adalah proses untuk mempelajari data-data keuangan untuk mengetahui posisi keuangan supaya dapat menentukan apa saja yang akan dipertimbangkan perkembangan perusahaan oleh pihak pengambil keputusan di masa yang akan datang.Rasio keuangan adalah alat analisis keuangan perusahaan untuk menilai kinerja suatu perusahaan berdasarkan perbandingan data keuangan yang terdapat pada pos laporan keuangan. Penilaian yang harus dilakukan terhadap laporan keuangan antara lain meliputi persoalan likuiditas, solvabilitas, profitabilitas dan aktivitas. Menurut (Harahap, 2018), rasio keuangan adalah angka yang diperoleh dari hasil perbandingan dari suatu pos laporan keuangan dengan pos lainnya yang mempunyai hubungan yang relevan dan signifikan.

Penilaian tingkat kinerja digunakan untuk menilai kinerja perusahaan pada tiap-tiap bagian yang telah diberikan wewenang dan tanggungjawab untuk menentukan perlu tidaknya suatu kebijakan atau prosedur yang baru untuk memperbaiki tiap bagian, proses atau produksi dalam 
perusahaan tersebut agar mencapai hasil yang lebih baik pada periode yang akan datang. Penilaian tingkat kinerja BUMN berlaku bagi seluruh BUMN non jasa keuangan yang diatur dalam Keputusan Menteri Badan Usaha Milik Negara Nomor: KEP-100/MBU/2002. Penilaian tingkat kinerja BUMN yang bergerak di bidang non jasa keuangan dibedakan antara BUMN yang bergerak dalam bidang infrastruktur dan BUMN yang bergerak dalam bidang non infrastruktur.

Indikator Penilaian BUMN berdasarkan Keputusan Menteri BUMN Nomor: KEP100/MBU/2002 yaitu Aspek Keuangan, Aspek Operasional, dan Aspek Administrasi.Penilaian pada PT. Pelabuhan Indonesia I (Persero) hanya dari segi aspek keuangan. Dalam penilaian aspek keuangan ini, indikator yang dinilai dan masing-masing bobotnya adalah seperti pada tabel 2 . dibawah ini.

Tabel 2. Daftar Indikator dan Bobot Aspek Keuangan BUMN

\begin{tabular}{|c|l|c|c|}
\hline \multirow{2}{*}{ No. } & \multicolumn{1}{|c|}{ Indikator } & Bobot & \\
\cline { 3 - 4 } & & Infra & Non Infra \\
\hline 1. & Imbalan Kepada Pemegang Saham (ROE) & 15 & 20 \\
\hline 2. & Imbalan Investasi (ROI) & 10 & 15 \\
\hline 3. & Rasio Kas & 3 & 5 \\
\hline 4. & Rasio Lancar & 4 & 5 \\
\hline 5. & Collection Periods & 4 & 5 \\
\hline 6. & Perputaran Persediaan & 4 & 5 \\
\hline 7. & Perputaran Total Aset & 4 & 5 \\
\hline 8. & Rasio Total Modal Sendiri Terhadap Total Aset & 6 & 10 \\
\hline & Total Bobot & 50 & 70 \\
\hline
\end{tabular}

Sumber : Keputusan Menteri BUMN Nomor: KEP-100/MBU/2002

\section{PenelitianTerdahulu}

Penelitian terdahulu ini menjadi acuan peneliti dalam melakukan penelitian sehingga peneliti dapat memperkaya teori yang digunakan dalam mengkaji penelitian yang dilakukan. Dari penelitian terdahulu, peneliti tidak menemukan penelitian dengan judul yang sama seperti judul penelitian peneliti. Namun peneliti mengangkat beberapa penelitian sebagai referensi dalam memperkaya bahan kajian pada penelitian ini. Berikut merupakan penelitian terdahulu berupa beberapa jurnal terkait dengan penelitian yang dilakukan peneliti.

Tabel 3. Penelitian Terdahulu

\begin{tabular}{|c|c|c|c|}
\hline No & $\begin{array}{c}\text { Nama Peneliti dan Judul } \\
\text { Penelitian }\end{array}$ & $\begin{array}{c}\text { Variabel dan } \\
\text { Metode } \\
\text { Penelitian } \\
\end{array}$ & Hasil Penelitian \\
\hline 1 & $\begin{array}{l}\text { (Suraya \& Meylani, 2019) } \\
\text { “Analisis Rasio Keuangan } \\
\text { Untuk Mengukur Kinerja } \\
\text { Keuangan Pada PT. Gas } \\
\text { Negara Tbk Periode 2013- } \\
2017 \text { (Berdasarkan } \\
\text { Keputusan Menteri BUMN } \\
\text { No: KEP- 100/MBU/2002)" }\end{array}$ & $\begin{array}{l}\text { Variabel Bebas: } \\
\text { Rasio Likuiditas, } \\
\text { Profitabilitas, } \\
\text { Aktivitas, } \\
\text { Solvabilitas } \\
\text { Variabel Terikat : } \\
\text { Kinerja Keuangan } \\
\text { Metode Penelitian } \\
\text { Kuantitatif dan } \\
\text { Deskriptif }\end{array}$ & $\begin{array}{l}\text { Rasio likuiditas, Rasio Likuiditas, } \\
\text { Profitabilitas, Aktivitas, } \\
\text { Solvabilitas diatas rata rata. } \\
\text { Berdasarkan Kep- Men BUMN } \\
\text { No: KEP-100/MBU/2002 bahwa } \\
\text { PT. Gas Negara Tbk, dapat } \\
\text { disimpulkan bahwa kinerja } \\
\text { keuangan perusahaan sehat. }\end{array}$ \\
\hline 2 & $\begin{array}{l}\text { (Nasution, 2019) “Analisis } \\
\text { Rasio Profitabilitas Dan } \\
\text { Likuiditas Untuk Mengukur } \\
\text { Kinerja Keuangan PT. } \\
\text { Pelabuhan Indonesia I } \\
\text { (Persero) Medan" }\end{array}$ & $\begin{array}{l}\text { Variabel Bebas : } \\
\text { Rasio Likuiditas } \\
\text { dan Profitabilitas } \\
\text { Variabel Terikat : } \\
\text { Kinerja Keuangan } \\
\text { Metode Penelitian }\end{array}$ & $\begin{array}{l}\text { Kinerja keuangan PT. Pelabuhan } \\
\text { Indonesia 1 (Persero) Medan , } \\
\text { Return On Asset, dan Current Ratio } \\
\text { mengalami penurunan skor disetiap } \\
\text { tahunnya, sedangkan Return On } \\
\text { Equity dan Cash Ratio mendapatkan } \\
\text { nilai yang bagus }\end{array}$ \\
\hline
\end{tabular}


Owner: Riset \& Jurnal Akuntansi

e-ISSN : 2548-9224 |p-ISSN : 2548-7507

Volume xx Nomor xx, Bulan Tahun

DOI : https://doi.org/10.33395/owner.Xxx.Xxx

\begin{tabular}{|c|c|c|c|}
\hline & & $\begin{array}{l}\text { Kuantitatif dan } \\
\text { Deskriptif }\end{array}$ & \\
\hline 3 & $\begin{array}{l}\text { (Wijaya, Hidayat, \& } \\
\text { Sulasmiyati, 2017) } \\
\text { "Analisis Rasio Keuangan } \\
\text { Untuk Menilai Kinerja } \\
\text { Keuangan BUMN (Studi } \\
\text { Kasus Pada PT. Aneka } \\
\text { Tambang (Persero) Tbk. } \\
\text { yang Terdaftar Di BEI } \\
\text { Tahun 2012-2015)" }\end{array}$ & $\begin{array}{l}\text { Variabel Bebas : } \\
\text { Rasio } \\
\text { Profitabilitas, } \\
\text { Likuiditas, } \\
\text { Aktivitas, } \\
\text { Solvabilitas } \\
\text { Variabel Terikat } \\
\text { : Kinerja } \\
\text { Keuangan } \\
\text { Metode } \\
\text { Penelitian : } \\
\text { Kuantitatif dan } \\
\text { Deskriptif }\end{array}$ & $\begin{array}{l}\text { Rasio solvabilitas, aktivitas dan } \\
\text { profitabilitas menunjukkan kinerja } \\
\text { keuangan yang kurang baik } \\
\text { meskipun pada tingkat likuiditas } \\
\text { diketahui dalam kondisi sangat } \\
\text { baik. Berdasarkan Surat Keputusan } \\
\text { Menteri BUMN Nomor: KEP- } \\
\text { 100/MBU/2002 untuk penilaian } \\
\text { tingkat kesehatan aspek keuangan } \\
\text { perusahaan PT. Aneka Tambang } \\
\text { (Persero) Tbk. periode } 2012 \\
\text { mendapatkan predikat sehat. } \\
\text { Namun pada tahun 2013- } 2015 \\
\text { memperoleh predikat kurang } \\
\text { sehat }\end{array}$ \\
\hline 4 & $\begin{array}{l}\text { (Maith, 2013)“Analisis } \\
\text { Laporan Keuangan } \\
\text { Dalam Mengukur Kinerja } \\
\text { Keuangan Pada PT. } \\
\text { Hanjaya Mandala } \\
\text { Sampoerna Tbk” }\end{array}$ & $\begin{array}{l}\text { Variabel Bebas } \\
\text { : Rasio } \\
\text { Likuiditas, } \\
\text { Solvabilitas, } \\
\text { Aktivitas, } \\
\text { Profitabilitas } \\
\text { Variabel } \\
\text { Terikat : } \\
\text { Kinerja } \\
\text { Keuangan } \\
\text { Metode } \\
\text { Penelitian : } \\
\text { Kuantitatif dan } \\
\text { Deskriptif }\end{array}$ & $\begin{array}{l}\text { Berdasarkan rasio likuiditas, rasio } \\
\text { aktivitas, rasio profitabilitas setiap } \\
\text { tahunnya mengalami peningkatan } \\
\text { sehingga keadaan perusahaan } \\
\text { dikategorikan dalam keadaan baik } \\
\text { sedangkan dari rasio solvabilitas } \\
\text { menunjukkan bahwa modal } \\
\text { perusahaan tidak lagi mencukupi } \\
\text { untuk menjamin hutang yang } \\
\text { diberikan oleh kreditor sehingga } \\
\text { keadaan perusahaan dikatakan dalam } \\
\text { keadaan tidak baik. }\end{array}$ \\
\hline 5 & $\begin{array}{l}\text { (Ridha, 2017)“Analisis Rasio } \\
\text { Keuangan Dalam Menilai } \\
\text { Kinerja Keuangan BUMN } \\
\text { (Studi Kasus Di PT. } \\
\text { Perkebunan Nusantara III } \\
\text { Medan)” }\end{array}$ & $\begin{array}{l}\text { Variabel Bebas : } \\
\text { Rasio } \\
\text { Profitabilitas, } \\
\text { Likuiditas, } \\
\text { Aktivitas, } \\
\text { Solvabilitas. } \\
\text { Variabel Terikat : } \\
\text { Kinerja } \\
\text { Keuangan } \\
\text { Metode } \\
\text { Penelitian : } \\
\text { Kuantitatif dan } \\
\text { Deskriptif }\end{array}$ & $\begin{array}{l}\text { Return on Equity (ROE), rasio kas, } \\
\text { collection periods, dan perputaran } \\
\text { persediaan berada pada kondisi yang } \\
\text { baik, sedangkan Return on } \\
\text { Investment (ROI), perputaran total } \\
\text { Asset, Rasio modal sendiri terhadap } \\
\text { total aset berfluktuasi setiap } \\
\text { tahunnya }\end{array}$ \\
\hline
\end{tabular}

\section{Kerangka Konseptual}


Owner: Riset \& Jurnal Akuntansi

e-ISSN : 2548-9224 |p-ISSN : 2548-7507

Volume xx Nomor xx, Bulan Tahun

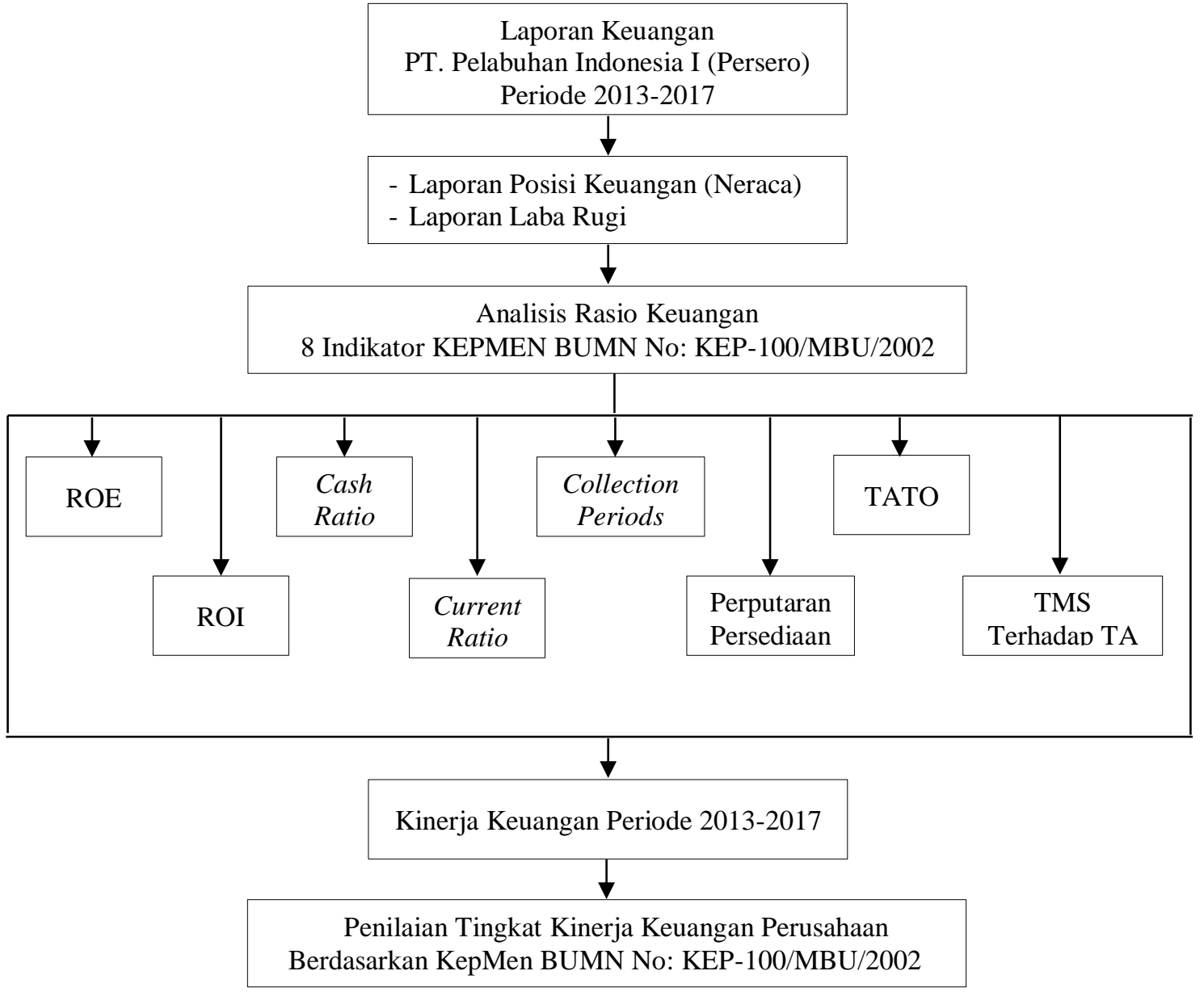

Sumber : Data Diolah Oleh Peneliti

Gambar 1. Kerangka Konseptual

\section{METODE}

Menurut (Sugiyono, 2019), tujuan penelitian secara umum dapat diartikan sebagai cara ilmiah untuk mendapatkan data yang valid dengan tujuan dapat ditemukan, dikembangkan, dan dibuktikan, suatu pengetahuan tertentu sehingga pada gilirannya dapat digunakan untuk memahami, memecahkan, dan mengantisipasi masalah. Desain penelitian yang digunakan metode deskriptif dengan pendekatan kuantitatif.Tempat penelitian ini dilakukan pada PT. Pelabuhan Indonesia I (Persero) yang beralamat di Graha Pelindo Satu Jl. Lingkar Pelabuhan No.1 Belawan, Medan 20411. Sumber data yang digunakan penelitian ini adalah laporan laba rugi dan laporan posisi keuangan (neraca) periode 2013-2017. Dalam penelitian ini, teknik pengumpulan data yang digunakan adalah studi dokumentasi, yaitu teknik pengumpulan data yang dilakukan dengan cara mengumpulkan data yang telah didokumentasikan atau dipublikasikan oleh perusahaan.

Metode analisis data pada penelitian ini adalah penilaian tingkat kinerja perusahaan BUMN dari aspek keuanganberdasarkan Keputusan Menteri BUMN Nomor: KEP-100/MBU/2002, yang dinilai dengan 8 (delapan) indikator sebagai berikut.

Tabel 4. Indikator Penilaian Aspek Keuangan BUMN

\begin{tabular}{|c|c|c|c|c|}
\hline No & Indikator & \multicolumn{2}{|l|}{ Rumus } & Rasio \\
\hline \multirow{2}{*}{1} & \multirow{2}{*}{ Return On Equity(ROE) } & Laba Setelah Pajak & \multirow{2}{*}{ x $100 \%$} & \multirow{2}{*}{ Profitabilitas } \\
\hline & & Modal Sendiri & & \\
\hline \multirow{2}{*}{2} & Return On Investment & EBIT + Penyusutan & \multirow{2}{*}{ x $100 \%$} & \multirow{2}{*}{ Profitabilitas } \\
\hline & $(\mathrm{ROI})$ & Capital Employed & & \\
\hline 3 & Cash Ratio & Kas+Bank+S.Berharga J.Pendek & x $100 \%$ & Likuiditas \\
\hline
\end{tabular}


Owner: Riset \& Jurnal Akuntansi

e-ISSN : 2548-9224|p-ISSN : 2548-7507

Volume xx Nomor xx, Bulan Tahun

DOI : https://doi.org/10.33395/owner.xxx.xxx

\begin{tabular}{|c|c|c|c|c|}
\hline & & Current Liabilities & & \\
\hline \multirow{2}{*}{4} & \multirow{2}{*}{ Current Ratio } & Current Assets & \multirow{2}{*}{ x 100\% } & \multirow{2}{*}{ Likuiditas } \\
\hline & & Current Liabilities & & \\
\hline \multirow{2}{*}{5} & \multirow{2}{*}{ Collection Periods } & Total Piutang Usaha & \multirow{2}{*}{ x $365 \mathrm{hr}$} & \multirow{2}{*}{ Aktivitas } \\
\hline & & Total Pendapatan Usaha & & \\
\hline \multirow{2}{*}{6} & \multirow{2}{*}{ Perputaran Persediaan } & Total Persediaan & \multirow{2}{*}{ x $365 \mathrm{hr}$} & \multirow{2}{*}{ Aktivitas } \\
\hline & & Total Pendapatan Usaha & & \\
\hline \multirow{2}{*}{7} & \multirow{2}{*}{$\begin{array}{l}\text { Total Asset Turn Over } \\
\text { (TATO) }\end{array}$} & Total Pendapatan & \multirow{2}{*}{ x $100 \%$} & \multirow{2}{*}{ Aktivitas } \\
\hline & & Capital Employed & & \\
\hline \multirow{2}{*}{8} & \multirow{2}{*}{ TMS Terhadap TA } & Total Modal Sendiri & \multirow{2}{*}{ x $100 \%$} & \multirow{2}{*}{ Solvabilitas } \\
\hline & & Total Aset & & \\
\hline
\end{tabular}

Sumber : Keputusan Menteri BUMN Nomor: KEP-100/MBU/2002

Tingkat kinerja perusahaan BUMN dari penilaian aspek keuangan berdasarkan Keputusan Menteri BUMN Nomor: KEP-100/MBU/2002 digolongkan menjadi 3 (tiga) kategori, yaitu :

Tabel 5. Tingkat Kinerja Penilaian Aspek Keuangan BUMN

\begin{tabular}{|c|c|c|}
\hline \multirow{2}{*}{ SEHAT } & AAA & Total Skor $>95$ \\
\cline { 2 - 3 } & AA & $80<$ Total Skor $<=95$ \\
\cline { 2 - 3 } & A & $65<$ Total Skor $<=80$ \\
\hline \multirow{3}{*}{ KURANG SEHAT } & BBB & $50<$ Total Skor $<=65$ \\
\cline { 2 - 3 } & BB & $40<$ Total Skor $<=50$ \\
\cline { 2 - 3 } & B & $30<$ Total Skor $<=40$ \\
\hline \multirow{3}{*}{ TIDAK SEHAT } & CCC & $20<$ Total Skor $<=30$ \\
\cline { 2 - 3 } & CC & $10<$ Total Skor $<=20$ \\
\cline { 2 - 3 } & C & Total Skor $<=10$ \\
\hline
\end{tabular}

Sumber : Keputusan Menteri BUMN Nomor: KEP-100/MBU/2002

HASIL

Berdasarkan laporan keuangan PT. Pelabuhan Indonesia I (Persero), berikut adalah hasil analisis kinerja keuangan PT. Pelabuhan Indonesia I berdasarkan pada Keputusan Menteri BUMN Nomor: KEP- 100/MBU/2002.

\section{Rasio Profitabilitas}

Tabel 6. Hasil Perhitungan Return On Equity (ROE)

\begin{tabular}{|c|c|c|c|c|}
\hline Tahun & Laba Setelah Pajak(1) & $\begin{array}{c}\text { Modal Sendiri } \\
(\mathbf{2})\end{array}$ & $\begin{array}{c}\text { ROE= } \\
(\mathbf{1}):(2) \mathbf{1 0 0}\end{array}$ & Skor \\
\hline 2013 & 488.915 .715 .337 & 1.813 .990 .907 .853 & $27 \%$ & 15 \\
\hline 2014 & 579.769 .375 .322 & 2.456 .931 .768 .709 & $24 \%$ & 15 \\
\hline 2015 & 700.118 .643 .316 & 2.552 .903 .848 .472 & $27 \%$ & 15 \\
\hline 2016 & 732.461 .233 .010 & 2.766 .789 .843 .350 & $26 \%$ & 15 \\
\hline 2017 & 804.008 .953 .015 & 2.815 .199 .744 .309 & $29 \%$ & 15 \\
\hline
\end{tabular}

Sumber : Data keuangan PT. Pelindo 1 2013-2017 yang telah diolah

Berdasarkan tabel 6, penggunaan skor yang ditetapkan pada Keputusan Menteri BUMN Nomor : KEP-100/MBU/2002, menunjukkan bahwa tingkat persentase ROE PT. Pelabuhan Indonesia I (Persero) pada tahun 2013-2017 memperoleh skor 15 yang merupakan skor tertinggi untuk BUMN Infrastruktur.

Tabel 7. Hasil Perhitungan Return On Investment (ROI)

\begin{tabular}{|c|c|c|c|c|}
\hline Tahun & EBIT+Penyusutan(1) & Capital Employed (2) & ROI =(1):(2)x100 & Skor \\
\hline 2013 & 743.901 .713 .965 & 4.092 .172 .810 .410 & $18 \%$ & 9 \\
\hline 2014 & 881.388 .410 .464 & 4.717 .766 .500 .251 & $19 \%$ & 10 \\
\hline 2015 & 1.071 .176 .736 .422 & 5.104 .962 .368 .286 & $21 \%$ & 10 \\
\hline
\end{tabular}


Owner: Riset \& Jurnal Akuntansi

e-ISSN : 2548-9224|p-ISSN : 2548-7507

Volume xx Nomor xx, Bulan Tahun

DOI : https://doi.org/10.33395/owner.xxx.xxx

\begin{tabular}{|l|l|l|l|l|}
\hline 2016 & 1.125 .375 .430 .565 & 6.500 .267 .699 .401 & $17 \%$ & 9 \\
\hline 2017 & 1.230 .928 .855 .088 & 7.223 .264 .110 .880 & $17 \%$ & 9 \\
\hline
\end{tabular}

Sumber : Data keuangan PT. Pelindo 1 2013-2017 yang telah diolah

Berdasarkan tabel 7, penggunaan skor yang ditetapkan pada Keputusan Menteri BUMN Nomor : KEP-100/MBU/2002, menunjukkan bahwatingkat persentase ROI PT. Pelabuhan Indonesia I (Persero) pada tahun 2013, 2016, dan 2017 masing-masing memperoleh skor 9, sedangkan tahun 2014 dan 2015 masing-masing memperoleh skor 10 yang merupakan skor tertinggi untuk BUMN Infrastruktur.

\section{Rasio Likuiditas}

Tabel 8. Hasil Perhitungan Cash Ratio

\begin{tabular}{|c|c|c|c|c|}
\hline Tahun & $\begin{array}{c}\text { Kas+Bank+Surat } \\
\text { Berharga (1) }\end{array}$ & $\begin{array}{c}\text { Current Liabilities } \\
(\mathbf{2})\end{array}$ & $\begin{array}{c}\text { Cash Ratio= } \\
(\mathbf{1}):(\mathbf{2}) \mathbf{x} 100\end{array}$ & Skor \\
\hline 2013 & 1.096 .770 .683 .664 & 611.997 .155 .060 & $179 \%$ & 3 \\
\hline 2014 & 1.272 .712 .369 .649 & 727.173 .225 .024 & $175 \%$ & 3 \\
\hline 2015 & 1.479 .384 .440 .740 & 1.114 .460 .837 .571 & $133 \%$ & 3 \\
\hline 2016 & 2.200 .769 .796 .594 & 1.511 .586 .760 .001 & $146 \%$ & 3 \\
\hline 2017 & 1.872 .411 .160 .625 & 1.823 .137 .753 .607 & $103 \%$ & 3 \\
\hline
\end{tabular}

Sumber : Data keuangan PT. Pelindo 1 2013-2017 yang telah diolah

Berdasarkan tabel 8, penggunaan skor yang ditetapkan pada Keputusan Menteri BUMN Nomor : KEP-100/MBU/2002, menunjukkan bahwa tingkat persentase cash ratio PT. Pelabuhan Indonesia I (Persero) pada tahun 2013-2017 memperoleh skor 3 yang merupakan skor tertinggi untuk BUMN Infrastruktur.

Tabel 9. Hasil Perhitungan Current Ratio

\begin{tabular}{|c|c|c|c|c|}
\hline Tahun & Current Asset(1) & Current Liabilities(2) & $\begin{array}{l}\text { Current Ratio=(1):(2) } \mathbf{x} \\
\mathbf{1 0 0}\end{array}$ & Skor \\
\hline 2013 & 1.274 .053 .559 .663 & 611.997 .155 .060 & $208 \%$ & 3 \\
\hline 2014 & 1.478 .307 .670 .217 & 727.173 .225 .024 & $203 \%$ & 3 \\
\hline 2015 & 1.766 .673 .446 .375 & 1.114 .460 .837 .571 & $159 \%$ & 3 \\
\hline 2016 & 2.481 .343 .189 .025 & 1.511 .586 .760 .001 & $164 \%$ & 3 \\
\hline 2017 & 2.209 .548 .446 .582 & 1.823 .137 .753 .607 & $121 \%$ & 2,5 \\
\hline
\end{tabular}

Sumber: Data keuangan PT. Pelindo $12013-2017$ yang telah diolah

Berdasarkan tabel 9, penggunaan skor yang ditetapkan pada Keputusan Menteri BUMN Nomor: KEP-100/MBU/2002, menunjukkan bahwa tingkat persentase current ratio PT. Pelabuhan Indonesia I (Persero) pada tahun 2013-2016 memperoleh skor 3 yang merupakan skor tertinggi untuk BUMN Infrastruktur, sedangkan pada tahun 2017 hanya memperoleh skor 2,5.

\section{Rasio Aktivitas}

Tabel 10. Hasil Perhitungan Collection Periods

\begin{tabular}{|c|c|c|c|c|}
\hline Tahun & $\begin{array}{c}\text { Total Piutang } \\
(\mathbf{1})\end{array}$ & $\begin{array}{c}\text { Total } \\
\text { Pendapatan } \\
\text { Usaha (2) }\end{array}$ & $\begin{array}{c}\mathbf{C P = ( 1 ) : ( 2 ) \times 3 6 5} \\
\mathbf{h r}\end{array}$ & Skor \\
\hline 2013 & 88.233 .772 .279 & 1.893 .989 .492 .513 & 17 Hari & 4 \\
\hline 2014 & 85.503 .925 .290 & 2.095 .520 .953 .158 & 15 Hari & 4 \\
\hline 2015 & 155.877 .564 .385 & 2.340 .724 .008 .344 & 24 Hari & 4 \\
\hline 2016 & 125.321 .592 .573 & 2.408 .899 .664 .963 & 19 Hari & 4 \\
\hline 2017 & 200.578 .860 .395 & 2.751 .106 .508 .170 & 27 Hari & 4 \\
\hline
\end{tabular}

Sumber : Data keuangan PT. Pelindo 1 2013-2017 yang telah diolah

Berdasarkan tabel 10, penggunaan skor yang ditetapkan pada Keputusan Menteri BUMN Nomor : KEP-100/MBU/2002, menunjukkan bahwa collection periods PT. Pelabuhan Indonesia I 
Owner: Riset \& Jurnal Akuntansi

e-ISSN : 2548-9224|p-ISSN : 2548-7507

Volume xx Nomor xx, Bulan Tahun

DOI : https://doi.org/10.33395/owner.xxx.xxx

(Persero) pada tahun 2013-2017 memperoleh skor 4 yang merupakan skor tertinggi untuk BUMN Infrastruktur.

Tabel 11. Hasil Perhitungan Perputaran Persediaan

\begin{tabular}{|c|c|c|c|c|}
\hline Tahun & $\begin{array}{l}\text { Total Persediaan } \\
\text { (1) }\end{array}$ & $\begin{array}{c}\text { Total Pendapatan Usaha } \\
\text { (2) }\end{array}$ & $\begin{array}{c}P P=(1):(2) \\
\times 365 \mathrm{hr}\end{array}$ & Skor \\
\hline 2013 & 11.934 .391 .115 & 1.893 .989 .492 .513 & 2 Hari & 4 \\
\hline 2014 & 17.302 .906 .753 & 2.095 .520 .953 .158 & 3 Hari & 4 \\
\hline 2015 & 21.226 .159 .916 & 2.340 .724 .008 .344 & 3 Hari & 4 \\
\hline 2016 & 20.116 .083 .124 & 2.408 .899 .664 .963 & 3 Hari & 4 \\
\hline 2017 & 23.716 .976 .975 & 2.751 .106 .508 .170 & 3 Hari & 4 \\
\hline
\end{tabular}

Sumber : Data keuangan PT. Pelindo 1 2013-2017 yang telah diolah

Berdasarkan tabel 11, penggunaan skor yang ditetapkan pada Keputusan Menteri BUMN Nomor : KEP-100/MBU/2002, menunjukkan bahwa perputaran persediaan PT. Pelabuhan Indonesia I (Persero) pada tahun 2013-2017 memperoleh skor 4 yang merupakan skor tertinggi untuk perusahaan BUMN Infrastruktur.

Tabel 12. Hasil Perhitungan Total Asset Turn Over (TATO)

\begin{tabular}{|c|c|c|c|c|}
\hline \multirow{2}{*}{ Tahun } & $\begin{array}{c}\text { Total Pendapatan } \\
(\mathbf{1})\end{array}$ & $\begin{array}{c}\text { Capital Employed } \\
\mathbf{( 2 )}\end{array}$ & $\begin{array}{c}\text { TATO= } \\
(\mathbf{1}):(\mathbf{2}) \mathbf{x} \mathbf{1 0 0}\end{array}$ & Skor \\
\hline 2013 & 1.933 .912 .058 .822 & 4.092 .172 .810 .410 & $47 \%$ & 1,5 \\
\hline 2014 & 2.122 .724 .013 .432 & 4.717 .766 .500 .251 & $45 \%$ & 1,5 \\
\hline 2015 & 2.364 .388 .859 .984 & 5.104 .962 .368 .286 & $46 \%$ & 2 \\
\hline 2016 & 2.360 .299 .730 .069 & 6.500 .267 .699 .401 & $36 \%$ & 1 \\
\hline 2017 & 2.559 .530 .864 .910 & 7.223 .264 .110 .880 & $35 \%$ & 1 \\
\hline
\end{tabular}

Sumber : Data keuangan PT. Pelindo 1 2013-2017 yang telah diolah

Berdasarkan tabel 12, penggunaan skor yang ditetapkan pada Keputusan Menteri BUMN Nomor : KEP-100/MBU/2002, menunjukkan bahwa tingkat persentase TATO PT.Pelabuhan Indonesia I (Persero) pada tahun 2013 dan 2014 memperoleh skor 1,5, tahun 2015 memperoleh skor 2, sedangkan tahun 2016 dan 2017 masing-masing memperoleh skor 1.

\section{Rasio Solvabilitas}

Tabel 13. Hasil Perhitungan TMS Terhadap TA

\begin{tabular}{|c|c|c|c|c|}
\hline Tahun & $\begin{array}{c}\text { Total Modal Sendiri } \\
(\mathbf{1})\end{array}$ & $\begin{array}{c}\text { Total Aset } \\
(\mathbf{2})\end{array}$ & $\begin{array}{c}\text { TMS Thd } \\
\text { TA=(1):(2)x 100 }\end{array}$ & Skor \\
\hline 2013 & 2.251 .547 .975 .800 & 4.579 .297 .077 .615 & $49 \%$ & 5,5 \\
\hline 2014 & 2.642 .622 .448 .434 & 4.855 .667 .611 .581 & $54 \%$ & 5 \\
\hline 2015 & 3.101 .412 .190 .011 & 5.491 .915 .582 .071 & $56 \%$ & 5 \\
\hline 2016 & 3.762 .363 .012 .079 & 7.301 .351 .310 .259 & $52 \%$ & 5 \\
\hline 2017 & 4.378 .339 .099 .031 & 8.507 .143 .315 .748 & $51 \%$ & 5 \\
\hline
\end{tabular}

Sumber : Data keuangan PT. Pelindo 1 2013-2017 yang telah diolah

Berdasarkan tabel 13, penggunaan skor yang ditetapkan pada Keputusan Menteri BUMN Nomor : KEP-100/MBU/2002,menunjukkan bahwa tingkat persentase Total Modal Sendiri Terhadap Total Aset PT. Pelabuhan Indonesia I (Persero) pada tahun 2013 memperoleh skor 5,5, sedangkan tahun 2014 hingga 2017 masing-masing memperoleh skor 5.

\section{PEMBAHASAN}

Berdasarkan hasil analisis kinerja keuangan PT. Pelabuhan Indonesia I berdasarkan pada Keputusan Menteri BUMN Nomor: KEP- 100/MBU/2002, berikut penilaian kinerja keuangan PT. Pelabuhan Indonesia I . 
Owner: Riset \& Jurnal Akuntansi

e-ISSN : 2548-9224|p-ISSN : 2548-7507

Volume xx Nomor xx, Bulan Tahun

DOI : https://doi.org/10.33395/owner.Xxx.xxx

\section{Penilaian Kinerja Keuangan}

Tabel 14. Penilaian Aspek Keuangan PT. Pelindo 1 (Persero)

\begin{tabular}{|l|c|c|c|c|c|c|}
\hline \multirow{2}{*}{\multicolumn{1}{|c|}{ Indikator Penelitian }} & \multicolumn{5}{|c|}{ Skor } & $\begin{array}{c}\text { Bobot } \\
\text { Standar }\end{array}$ \\
\cline { 2 - 7 } & $\mathbf{2 0 1 3}$ & $\mathbf{2 0 1 4}$ & $\mathbf{2 0 1 5}$ & $\mathbf{2 0 1 6}$ & $\mathbf{2 0 1 7}$ & 15 \\
\hline $\begin{array}{l}\text { Imbalan Pemegang Saham } \\
\text { (ROE) }\end{array}$ & 15 & 15 & 15 & 15 & 15 & 10 \\
\hline Imbalan Investasi (ROI) & 9 & 10 & 10 & 9 & 9 & 3 \\
\hline Rasio Kas (Cash Ratio) & 3 & 3 & 3 & 3 & 3 & 3 \\
\hline Rasio Lancar (Current Ratio) & 3 & 3 & 3 & 3 & 2,5 & 4 \\
\hline Collection Periods (CP) & 4 & 4 & 4 & 4 & 4 & 4 \\
\hline Perputaran Persediaan (PP) & 4 & 4 & 4 & 4 & 4 & 4 \\
\hline $\begin{array}{l}\text { Total Assets Turn Over } \\
\text { (TATO) }\end{array}$ & 1,5 & 1,5 & 2 & 1 & 1 & 4 \\
\hline $\begin{array}{l}\text { Total Modal Sendiri Terhadap } \\
\text { Total Aset }\end{array}$ & 5,5 & 5 & 5 & 5 & 5 & $\mathbf{5 0}$ \\
\hline \multicolumn{1}{|c|}{ Total Bobot } & $\mathbf{4 5}$ & $\mathbf{4 5 , 5}$ & $\mathbf{4 6}$ & $\mathbf{4 4}$ & $\mathbf{4 3 , 5}$ & $\mathbf{5 0}$ \\
\hline
\end{tabular}

Sumber: Data keuangan PT.Pelindo 1 2013-2017 yang telah diolah

Dari perhitungan tabel 14, penilaian aspek keuangan PT. Pelabuhan Indonesia I (Persero) menunjukkan bahwa perusahaan mengalami peningkatan selama tahun 2013 hingga 2015, selanjutnya selama tahun 2016 dan 2017 mengalami penurunan. Hal ini dapat dilihat dari nilai total bobot penilaian secara keseluruhan selama periode tersebut. Pada tahun 2013 memperoleh skor sebesar 45, tahun 2014 sebesar 45,5, tahun 2015 sebesar 46, tahun 2016 sebesar 44, dan tahun 2017 sebesar 43,5. Adanya peningkatan atau penurunan penilaian aspek keuangan disebabkan oleh fluktuasi setiap tahunnya yaitu pertumbuhan ROI, perputaran persediaan, TATO dan TMS terhadap TA yang tidak terlalu signifikan sedangkan indikator lainnya mengalami fluktuasi yang cukup signifikan.

Berdasarkan hasil penilaian aspek keuangan PT. Pelabuhan Indonesia I (Persero) periode 2013-2017, maka total skor yang diperoleh untuk menilai tingkat kinerja keuangan, yaitu total bobot dari hasil penilaian aspek keuangan dibuat ekuivalennya. Hasil akhir kategori kinerja perusahaan dapat diperoleh dengan cara membagi total bobot dari hasil penilaian aspek keuangan dengan bobot standar yaitu 50\%. Berikut penilaian tingkat kinerja keuangan pada PT. Pelabuhan Indonesia I (Persero) periode 2013-2017.

Tabel 15. Penilaian Tingkat Kinerja Keuangan PT. Pelindo I (Persero)

\begin{tabular}{|c|c|c|c|c|c|c|}
\hline Tahun & $\begin{array}{c}\text { Total } \\
\text { Bobot } \\
(\mathbf{1})\end{array}$ & $\begin{array}{c}\text { Bobot } \\
(\mathbf{2})\end{array}$ & $\begin{array}{c}\text { Total Skor } \\
(\mathbf{1}):(\mathbf{2})\end{array}$ & Nilai & Kategori & Predikat \\
\hline 2013 & 45 & $50 \%$ & 90 & $80<\mathrm{TS}<=95$ & AA & SEHAT \\
\hline 2014 & 45,5 & $50 \%$ & 91 & $80<\mathrm{TS}<=95$ & AA & SEHAT \\
\hline 2015 & 46 & $50 \%$ & 92 & $80<\mathrm{TS}<=95$ & AA & SEHAT \\
\hline 2016 & 44 & $50 \%$ & 88 & $80<\mathrm{TS}<=95$ & AA & SEHAT \\
\hline 2017 & 43,5 & $50 \%$ & 87 & $80<\mathrm{TS}<=95$ & AA & SEHAT \\
\hline
\end{tabular}

Sumber: Data keuangan PT. Pelindo $12013-2017$ yang telah diolah

Berdasarkan hasil analisis pada tabel diatas, hasil yang diperoleh menunjukkan bahwa tingkat kinerja keuangan PT. Pelabuhan Indonesia I (Persero) periode 2013-2017 berdasarkan Keputusan Menteri BUMN Nomor: KEP-100/MBU/2002 memperoleh predikat Sehat dengan kategori AA secara berturut-turut.

\section{KESIMPULAN}

Hasil kinerja keuangan PT. Pelabuhan Indonesia I (Persero) periode 2013-2017 yang di analisis dengan rasio keuangan berdasarkan Keputusan Menteri BUMN Nomor: KEP100/MBU/2002, antara lain: Tingkat rasio profitabilitas yang dinilai dengan Return On Equity 
(ROE) dan Return On Investment (ROI) pada PT. Pelabuhan Indonesia I (Persero) periode 20132017 dalam kondisi baik. Hal ini mengindikasikan bahwa perusahaan telah mampu memanfaatkan aktiva dan sumber daya yang dimiliki untuk memperoleh laba (keuntungan) yang dicapai. Tingkat rasio likuiditas yang dinilai dengan cash ratio dan current ratio padaPT. Pelabuhan Indonesia I (Persero) periode 2013-2017 diketahui dalam kondisi baik. Hal ini mengindikasikan bahwa perusahaan masih mampu untuk memenuhi kewajiban jangka pendeknya.Tingkat rasio aktivitas yang dinilai dengan Collection Periods (CP), Perputaran Persediaan (PP), dan Total Asset Turn Over (TATO) pada PT. Pelabuhan Indonesia I (Persero) periode 2013-2017 dalam kondisi kurang baik. Dapat dilihat pada Total Asset Turn Over (TATO) perusahaan tidak dapat memperoleh skor tertinggi selama periode tersebut. Hal ini mengindikasikan bahwa perusahaan kurang optimal dalam memanfaatkan dan mengelola aktiva yang dimiliki dalam menghasilkan pendapatan.Tingkat rasio solvabilitas yang dinilai dengan Total Modal Sendiri Terhadap Total Aset (TMS Terhadap TA) pada PT. Pelabuhan Indonesia I (Persero) periode 2013-2017 dalam kondisi baik. Hal ini mengindikasikan bahwa perusahaan tidak banyak menggunakan hutang-hutangnya untuk membiayai aktiva yang dimiliki.Berdasarkan Keputusan Menteri BUMN Nomor: KEP100/MBU/2002 untuk penilaian tingkat kinerja keuangan PT. Pelabuhan Indonesia I (Persero) periode 2013-2017 mendapatkan predikat sehat dengan kategori AA secara berturut-turut walaupun dengan total skor yang berbeda.

\section{REFERENSI}

BUMN, K. (2002). Keputusan Menteri Badan Usaha Milik Negara Nomor: KEP-100/MBU/2002 Tentang Penilaian Tingkat Kinerja Badan Usaha Milik Negara. http://jdih.bumn.go.id/lihat/KEP-100/MBU/2002.

Fahmi, I. (2017). Manajemen Keuangan Dan Pasar Modal. Jakarta: Mitra Wacana Media.

Harahap, S. S. (2018). Analisis Kritis Atas Laporan Keuangan. Edisi Pertama. Jakarta: Rajawali Pers.

Hery, H. (2015). Analisis Kinerja Manajemen. Jakarta: PT Grasindo.

Indonesia, I. A. (2019). Standar Akuntansi Keuangan: PSAK No.1 - Penyajian Laporan Keuangan. Jakarta: Salemba Empat.

Informasi, B. T. (2017). Annual Report PT. Pelabuhan Indonesia I (Persero) Tahun 2013-2017. https://www.pelindo1.co.id/id/profil/Annual- Report.aspx.

Kasmir, K. (2015). Analisis Laporan Keuangan. Jakarta: PT Raja Grafindo Persada.

Maith, H. A. (2013). Analisis Laporan Keuangan dalam Mengukur Kinerja Keuangan Pada PT. Hanjaya Mandala Sampoerna Tbk. Jurnal EMBA Vol.1 No.3 September 2013, 619-628.

Munawir, M. (2016). Analisa Laporan Keuangan. Yogyakarta: Liberty.

Nasution, S. F. (2019). Analisis Rasio Profitabilitas Dan Likuiditas Untuk Mengukur Kinerja Keuangan PT. Pelabuhan Indonesia I (Persero). Skripsi. Medan: Universitas Muhammadiyah Sumatera Utara.

Ridha, M. (2017). Analisis Rasio Keuangan Dalam Menilai Kinerja Keuangan BUMN (Studi Kasus Di PT. Perkebunan Nusantara III). Skripsi. Medan: Universitas Islam Negeri Sumatera Utara.

Rudianto, R. (2013). Akuntansi Manajemen. Jakarta: Erlangga.

Sugiyono, S. (2019). Metode Penelitian Pendidikan. Bandung: Alfabeta.

Suraya, A., \& Meylani, S. (2019). Analisis Rasio Keuangan Untuk Mengukur Kinerja Keuangan Pada Pt. Gas Negara Tbk Periode 2013 - 2017 (Berdasarkan Keputusan Menteri BUMN Nomor: KEP-100/MBU/2002). Jurnal Sekuritas, Vo.2,No.3, Mei 2019, 101-116.

Wijaya, F., Hidayat, R. R., \& Sulasmiyati, S. (2017). Analisis Rasio Keuangan Untuk Menilai Kinerja Keuangan BUMN (Studi Kasus Pada PT. Aneka Tambang (Persero) Tbk. Yang Terdaftar Di BEI Tahun 2012-2015). Jurnal Administrasi Bisnis (JAB)|Vol. 45 No.1 April 2017, 102-110. 